\title{
Domination of The Political STRENGTH OF DARUSSALAM HOUSE IN The Village of Gontor Ponorogo
}

International Journal of Innovation Review

https://ijireview.com/ijir

e-ISSN:

p-ISSN:

IJIR REVIEW 1 (1) (2020): 1-6

DOI:-

Keywords: elite-mass interaction, formal-informal power, and political domination

\section{'Corresponding Author \\ Phone \\ Email : rizcaputri.fisip@uwks. \\ ac.id}

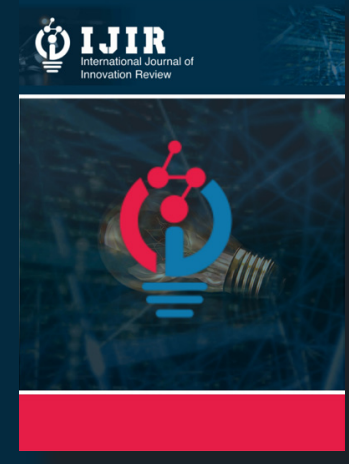

(C) Rizca Yunike Putri

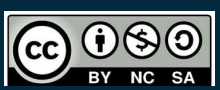

This work is licensed under the Creative Commons AttributionNonCommercial-ShareAlike 4.0 International License.

\section{Rizca Yunike Putri*}

Wijaya Kusuma University Surabaya

Jl. Dukuh Kupang XXV / 54, Surabaya, Jawa Timur

Received: 2 June 2020; Accepted: 12 July 2020; Published online: 30 September 2020

\section{Abstract}

The reality of modern political life today affects the whole structure of people's lives. One of the variables in interesting political dynamics is the existence of political actors as the driving force that makes political events more exciting and also interesting to discuss. This is what we know better as the dynamics of the elite and mass relations. For this reason, the purpose of this study is to look at the dynamics of political movements that show the reality of the interaction of elites and masses in villages that have their uniqueness, where usually the elite as the central power, both formal and informal, usually have an influence that is not rational but more traditional affection. By using the field observation method, it was found that cottage Darussalam had a strong dominance. In gontor village, the elite and the masses have a very strong influence. In terms of the elite, in gontor, which is $2 / 3$ of the territory controlled by the modern Darussalam Islamic boarding school, formally and informally - the elite - are still connected and influencing one another.

\section{INTRODUCTION}

The reality of modern political life today affects the entire structure of society. It is not only in big cities that we understand it is full of individual attitudes and the desire to gain power. But life in rural areas also gets involved in local political dynamics (Saputra \& Abidin, 2017). Although the life of the village community is more of a guyub and traditional (affection).

One of the variables in interesting political dynamics is the existence of political actors as the driving force that makes political events more exciting and also interesting to discuss. This is what we know better as the dynamics of the elite and mass relations. Where the elite plays a role as a driving force and also have power over the masses who are controlled subjects (Ningsih et al., 2018, p.68). The variables that will influence the elite-mass relationship are the source of power, the form of leadership, and how these elites use their power to control the masses.

The dynamics of political movements that show the reality of the interaction of elites and masses in the village have their own peculiarities. Where the elite as the center of power, both formal and informal, usually has an influence that is not rational but more traditional (Tokan \& Ola, 2020, p. 2). This is still related to the general paradigm of village communities that are still traditional and uphold the principle of kinship in them. So that usually the masses give an assessment of the elite in the village based on 
feelings, can a sense of admiration, charisma, trust, etc.

No exception in the village of Gontor, Ponorogo Regency. If described, the village of Gontor fits its motto, Gontor, the Village of Damai is truly peaceful and gives the impression of village life-guyub and has a high sense of cooperation. However, what caught our attention when conducting field observation activities was the domination of power exercised by the village head. We see it from every policy taken by the village head whose impression is taken by the village head himself.

However, in each of these policies, there must be someone or a separate controller who controls every step of the village head in providing his policies. Given the character of the village head who is a tactical leader but lacks depth in thinking. If we draw a red thread it cannot be denied that someone is in control of the village head. What occurred to us was who, where did the village head come from, and what had affected him the most? For four days of observing, we obtained fairly convincing data that the village head, who is a native of Gontor village as well as an alumnus of the Islamic Boarding School of Darussalam, is a boarding school cadre and almost all the thoughts and actions of the village head have an orientation aimed at Darussalam itself.

Besides, if we look at the reality that exists in the village of Gontor, where the villagers still have a traditional paradigm but the unique thing is that the village economic development is classified as advanced and well-managed with the job opportunities provided by the Cottage Pesantren Modern Darussalam (Cottage Gontor). So that the impression when we conducted this village observation was that it was like an independent village and an Islamic boarding school with sufficient economic resources. This can be seen from the existence of a cooperative unit, the independent drinking water business La Tanza, agriculture, and many more. But back again, there is always Cottage Darussalam behind it as a pioneer. Even the village community becomes the main human resource, both expert staff and only ordinary employees in it. Besides, the boarding school also provides education costs for Gontor villagers who wish to continue their studies at the Darussalam Islamic Boarding School.

However, it turns out that Cottage Gontor does not only have a role in the economic and social sectors but also politics in the village. This can be seen during the election of the village head 2 years ago with the existence of a single candidate for village head who came from the scope of the Gontor Islamic Boarding School. And what is even more surprising is that whoever the candidate whose background comes from Cottage Gontor and has the blessing of Kiyai, the leader of the cottage will win from any other candidate. It is not uncommon for candidates other than who will be willing to resign if there are already candidates from the lodge. This shows that the real elite in the political life of Gontor village is the Darussalam Ponpes.

From this background, the authors are interested in examining the political domination of Cottage Darussalam in Gontor Village because it is based on the interesting reality of the dynamics of elite-mass relations in the village of Gontor. With the assumption that Cottage Darussalam through the village head has a strong authority to control all existing systems in the village of Gontor. Implemented in political power in Gontor Village.

Wibisono and Djumadin (2020) have done a lot of research related to elite relations with the community regarding the relations and interests of local party elites in the autonomy era. He sees the era of regional autonomy not only giving birth to a new government system but also giving birth to the dynamics of elite circulation in increasingly complex regions, especially for political party elites.

Amin (2017) examines the elite and power in rural communities. The research was conducted in Rias Village, Toboali District, South Bangka Regency. The results of his research show that the implementation of government in the village is still full of manipulation by a certain group of elites whose power places the community as the object of policy. The power that is in the hands of this elite creates domination so that the community does not have sufficient access to influence or give feedback on the administration of the government that is currently taking place.

In contrast to the above research, this study aims to see the political power/authority of Cottage Darussalam in Gontor Village and the relationship between the elite and the people of Gontor Village. The research also focuses on how the real political reality that exists in the village is a reflection of the life of the people in the village of Gontor and looks at the patterns that occur in it. Then the authors also analyze who benefits from the political process in the village by looking at which direction the village's local policies lead to whose interests and the policy allocation itself.

\section{METHOD}

This type of research used in this approach is a qualitative research method using a descriptive approach that emphasizes interviews and observations of the community to be studied (Bungin, 2006). On this occasion of writing, we focus on the political dynamics, namely the political power itself in Gontor Village which is carried out by the Darussalam pesantren. In the beginning, in our field study activities, we saw the political power of the elite-mass from the running of 
the PNPM-Mandiri government program. However, in this article, we focus on the dominance of Cottage Darussalam in the life of the Gontor community. Data collection methods in this study were unstructured observation and interviews. Observations, in this case, are related to our observations of the results of program implementation and the lives of the surrounding communities related to the title of this study. These observations can take the form of direct exposure to the lives of local communities to obtain appropriate documentation.

\section{RESULTS AND DISCUSSION}

Regionally, Gontor Village is one of the villages located in the Mlarak sub-district, Ponorogo Regency. The area of Gontor village is 2/3 of the building area of Cottage Darussalam. Gontor Village is divided into two hamlets, namely south hamlet and north hamlet. North hamlet has extensive agricultural land and for the livelihoods of the population, most of them work as farmers. Meanwhile, the south hamlet belongs to the Darussalam Islamic Boarding School. Differently, the community groups, it seems, in addition to dividing the territory, they also divide the social groups of the village community. Where in the South hamlet they tend to side with the Cottage and the North Hamlet tends to be somewhat disobedient to the Cottage. However, since the bureaucratic control is controlled by the majority of Southern citizens, any policy in the village is easy to implement without the participation of the North.

Two-thirds of the area of Gontor village is the Darussalam Islamic Boarding School building. Perhaps the first impression that comes to mind is that "the area of the hut and the area of the village is bigger than the village". Of course, it refers to the land that is controlled. And this affects life in the village of Gontor itself. Both economically, culturally, and politically. Economically, the population of Gontor Village, approximately $80 \%$ of its residents, do not have land to farm. Its residents depend on their livelihoods from the huts, while others are farmers and others (civil servants and private sector).

The villagers themselves and the campus residents in the Modern Darussalam Islamic boarding school have a very helpful relationship with each other. About $80 \%$ of the population depends on their livelihood to work as employees of Cottage Darussalam. Some of them work as cooks, cottage cleaners, food suppliers, etc. However, not a few of the residents in north hamlet work as staff and also employees of Cottage Darussalam.

Meanwhile, the residents of the Cottage who are teaching staff both from the village of Gontor or outside the village live in the area around the cottage. Teaching staff who are still young and notyet married are placed in special dormitories for them with adequate facilities, complete with clothing for duty. Apart from teaching, they are also students of the Faculty of Sharia, Tarbiyah, and Usuludin who were opened for them. All learning facilities are provided by the lodge. So the task of these young teachers, of course, the best alumni from the lodge, is to learn and teach, those with good achievements are sent to universities in the Middle East. The Kiyai and teaching staff are provided housing on campus. They do not get wages from the cottage, except for a very limited amount of money for special purposes. The cottage provided for them included two hectares of rice fields to be worked on with profit sharing, rice, and side dishes for daily needs covered by the cottage, as well as housing complete with electricity and free clean water.

Meanwhile, the forms of participation of villagers with campus activities and construction include:

1. Approximately $80 \%$ of the total population of Gontor villagers who do not have agricultural land work in the cottage in terms of maintenance, construction of a new campus, and others.

2. Snacks purchased by the students, totaling approximately 4000 people, are the work of the mothers around the lodge. The cottage canteen buys snacks from the mothers around the lodge and the students are good enough consumers for the work of these mothers.

3. Many students do not have time to iron their clothes. This is a good side job for mothers who work for it.

4. The distance between the cottage and the small town of Ponorogo is about $15 \mathrm{~km}$ if it is reached by foot far enough. The number of sado (dokar) is not balanced with the number of students who will go to Ponorogo for recreation. To overcome this difficulty, many residents provide bicycles for rent to students going to Ponorogo. Of course, this is quite a livelihood for the villagers. Not a few villagers have improved their standard of living by renting bicycles to the students.

\section{A. The Political Power of Pondok Darussalam}

In sociological theory, according to Max Weber, leadership is divided into three types (Arifin, 2015, p. 15), namely:

\section{1) Traditional Leadership}

People who hold this leadership believe that the spirit of leadership and wisdom can be passed down the bloodline. They believe that certain families can maintain leadership character. Monarchy can be born in a traditional society. People who glorify traditions are not only people who lived in the past. Even in modern society, some communities still adhere to tradition. The royal system in England, 
for example, is one example of a society that still holds traditions in the field of leadership. Another example is Japan. They are led by an emperor (tenno haika) from generation to generation. Even though tenno haika is no longer believed to be descendants of Amaterasu Omikami (the Sun God), they still feel comfortable being led by the imperial family. Likewise countries such as Saudi Arabia and several countries in Europe.

\section{2) Charismatic Leadership}

This type of leader is considered to have supernatural abilities, namely traits and abilities above the average human. They are people who are considered to have divine abilities so that they can do things that ordinary people cannot. The prophets of old were charismatic leaders. They are equipped with miracles which are supernatural powers. Such a leader is not born every time, and cannot be born. Such leaders are always respected for their views and decisions.

\section{3) Rational Legal Leadership}

Leadership is obtained through rules and rational rules designed to filter out a leader. People who have developed rational rules in determining a leader usually do not see someone based on their descent or character. They set criteria or requirements, and are determined through deliberations or voters. Rational or legal authority is the authority that is based on the legal system prevailing in the society. The legal system here is understood as rules that have been recognized and adhered to by the community, and have even been strengthened by the State. The authority based on the legal system must also be seen whether the legal system is based on tradition, religion, or other. Then the relationship with the power system must also be examined and also tested whether or not the legal system is compatible with the cultural system of society, so that life can run calmly and peacefully. The appropriate form of leader to illustrate this is the authority possessed by the Village Head. The leader in this village area is determined based on the consensus of the citizens, which is then legalized by State regulations (Village Head).

Meanwhile, the definition of the elite in the political context means a small group of people who have power and allocate it to the society where the small group plays a role in making and implementing political decisions (Haryanto, 2009). While the masses are the wider community ruled by a group of elites. In the political life of village communities, two concepts affect political life in the community, namely Traditional Authority Relations (TAR) and Patron Client Relations (PCR) (Rochadi, 2016). By using a leadership approach in examining political movements in the village, we will further identify the phenomenon of rural communities related to the relationship between the elite and the masses in the village community. Elite power is divided into two parts, namely formal and informal power (Simanjuntak, 2018). Informal power includes government institutions in the village, while informal power includes the cultural view, political cultures that exist in the village community, such as Kiyai, Cottage pesantren, elders, and so on.

The cottage has power in various areas of life in the village of Gontor. Among them are economic, social, cultural, and political terms. In the case of the cottage economy, it has a program of providing capital loans through cottage savings and loans cooperatives, cultivating agricultural areas on cottage land which are devoted to the production of cottage needs, opening jobs as cottage employees and staff, to distributing people's consumption materials through opened shops. by the lodge (supermarket and grocery store). In terms of socio-culture, Cottage provides its effects through religious conditioning in the village (recitation activities, marawis, etc.) and provides fee relief for residents who wish to continue their schooling in the Cottage. Meanwhile, in terms of politics, Cottage cadres have always been central in society both in village government institutions and socially.

When we understand where and what are the sources of power for an elite, it can be seen that Cottage Gontor's political power comes from economic control (agriculture, capital, and economic distribution), control of social and cultural systems, leadership succession systems (controlled by Cottage Alumni cadres). ) as well as the brand image built by the cottage itself through the cottage approach and conditioning towards the residents.

To further strengthen the power position of the Cottage in the village, the Cottage officials have taken several strategic actions. Among other things, apart from controlling economic resources and social influence, namely applying the politics of mass influence by giving a good brand image through the alumni who come from Gontor residents themselves, mandating the original alumni of Gontor residents to advance in village head elections, and also village formal institutions. other. This is of course to attract the sympathy of the villagers through leadership patterns for the alumni of the Cottage Darussalam. And if there are already candidates from Cottage alumni who run as village heads, other candidates will be willing to resign from the participants in the village head election.

The sources of power as well as the strategies possessed by this Cottage also influence how the movement of the Cottage in the village influences every policy that will be formulated by the village government. The concrete thing is the construction of drainage funded by PNPM Mandiri which is 
built around the hut which is a flood area. Given its history full of conflicts between the residents of the cottage and also the residents of Gontor Village. Apart from the PNPM program which was used as drainage development, the distribution of funds was also too focused on the area of south hamlet which was a cottage area, so that the impression of village development was only for the southern region. Which all policies aim to smooth cottage activities. This is not a difficulty considering that the Cottage has the power to control politics in the village of Gontor assisted by its cadres who have formal power in the Cottage. So indirectly the formal power that exists in the village is the true power of the alumni of Cottage Daarussalam even though there are open elections.

Then in the social sector, there is very strong domination of the cottage which can be seen during big events such as the 17 August celebration where residents have to match the village decorations with cottage decorations that use all green colors. So it can be concluded that the Cottage authority has a traditional kind of authority. Whereas an elite, the lodge gives power from generation to generation to its cadres. In concrete terms, the village head always comes from an active alumnus of the Cottage. But informing the trust of village leaders towards their people, the village head has a charismatic type that can be seen from all the behavior and praise given by the residents when we make observations there and are supported by legal-formal power.

\section{B. Elites and Communities in Gontor Village}

With the presence of Cottage, of course, it has a positive influence on village development. Namely with the development of the economic and sociocultural establishment. Of course, the residents give great appreciation and also return the gratitude for the existence of the cottage in the village of Gontor. Especially with village leaders, the majority of whom are cottage alumni and who are considered by villagers to have authority. Moreover, it is supported by the cottage economy which provides employment opportunities for residents who do not have land to farm. In other words, there is a mutualism symbiotic relationship in terms of the economy of the residents and Cottage Darussalam.

The attitude of the residents towards the lodge also varies. However, almost $75 \%$ of the informants we interviewed had a positive assessment of the presence of the Cottage. Especially in terms of helping the economy of residents who are helped because the cottage has a variety of independent businesses and staffing cottage that require a lot of employees.

But in reality, the political freedom of the cottage is not fully guaranteed. Referring to the basic concept of elite-mass leadership that is that there is a minority who controls the majority and the recognition of individual rights, in Gontor village it can be observed that the Cottage - citizen alumnus and cottage leaders - are in a minority compared to the number of residents and Cottage is subtly lacking in terms of recognition of individual rights. A concrete example is during the election of the village head, before the current village head, there were 2 candidates, one from an ordinary villager and one from a Cottage alumnus. Knowing that his rival is an alumnus of the Cottage, a candidate who from ordinary citizens withdrew from the election because he was aware of losing the election.

So it can be concluded that the existence of Cottage Darussalam as an educational institution has a positive influence on rural development in the economic sector. However, the negative thing is that the movement of the citizens in political and social terms is limited by the Cottage parties.

\section{Conclusion}

The dynamics of democratic life are indeed very interesting to discuss. What more if in understanding it uses a leadership / elite-mass approach which will certainly illustrate the dynamics of the relationship between the elite and the masses. If the context of the writing subject is in the village, the elite can be seen with the traditional or patron concept.

Based on data and analysis, the authors conclude based on the formulation of the problem, namely:

\section{1) Pondok Darussalam Authority in GontorVillage}

The cottage has power in various areas of life in Gontor Village. Among them are economic, social, cultural, and political terms. The source of the power of an elite, it can be seen that Pondok Gontor's political power comes from economic control (agriculture, capital, and economic distribution), control of social and cultural systems, leadership succession systems (controlled by Pondok alumni cadres) and also brand image. To further strengthen the power position of the cottage in the village, the cottage officials have taken several strategic actions. So it can be concluded that the cottage authority has a traditional kind of authority.

\section{2) Elite and Community Relations in Gontor Village}

The presence of the cottage, of course, has a positive influence on village development. However, the negative thing is that the movement of the citizens in political and social terms is limited by the cottage parties.

In the life of the community in Gontor village, cottage Darussalam provides insurmountable 
pressures to control all elements of village life by maximizing the potential of the cottage. All will return to the main objective of the cottage, of course, to maintain power and also its existence in the village of Gontor so that all activities in the cottage can run smoothly.

However, if this situation continues, of course, it will bring problems to both the lodge and the villagers. Efforts that can be made so that there is a balance between the power of the cottage and the residents is to balance the power by including representatives from the North Hamlet and also evaluating the village government. And the villagers also hope to apply their awareness to be open to seeing the reality of the power of the cottage, which even though they are in power informally dominate village life.

\section{REFERENCES}

Amin, K. (2017). Elit dan Kekuasaan pada Masyarakat Desa. Jurnal Sosiologi USK (Media Pemikiran \& Aplikasi), 11(2), 167-187. http://e-repository. unsyiah.ac.id/JSU/article/view/10096

Arifin, Z. (2015). Kepemimpinan Kiai dalam Ideologisasi Pemikiran Santri di PesantrenPesantren Salafiyah Mlangi Yogyakarta. INFERENSI, 9(2), 351-372. https://doi. org/10.18326/infsl3.v9i2.351-372

Bungin, B. (2006). Metode Penelitian Kualitatif.

Haryanto. (2009). Elit Politik Lokal dalam Perubahan Sistem Politik. Jurnal Ilmu Sosial Dan Ilmu Politik, 13(2), 131-148. https://doi. org/10.22146/jsp.10958

Ningsih, S. T., Sucipta, U. J. S. J., \& Pertiwi, M. S. (2018). IMAJINASI DESA IMPIAN: Konstruksi Media dalam Pengembangan Desa Wisata di Desa Ranuklindungan Kabupaten Pasuruan. The Journal of Society \& Media, 2(1), 65. https:// doi.org/10.26740/jsm.v2n1.p65-80

Rochadi, A. S. (2016). Pergerakan Pekerja Muslim: Studi terhadap Sarbumusi dan Persaudaraan Pekerja Muslim Indonesia. Konferensi Nasional Sosiologi V, 1-18. http://sosiologi.fisip.unand. ac.id/in/rumah/1086-prosiding-konferensinasional-sosiologi-V

Saputra, E., \& Abidin, Z. (2017). Dinamika Konflik Sosial Politik pada Masyarakat Perdesaan ( Studi Kasus di Gampong Kuta Aceh, Kecamatan Seunagan Kabupaten Nagan Raya). Jurnal Ilmiah Mahasiswa FISIP Unsyiah, 4(4), 22-28. www.jim.unsyiah.ac.id/FISIP

Simanjuntak, N. H. (2018). Strategi Pemuda Menuju Jalan Kekuasaan Politik Formal dan Informal(Studi Kasus di Kota Tanjungpinang) [Universitas Maritim Raja Ali Haji ]. https:// fisip.umrah.ac.id//

Tokan, F. B., \& Ola, U. (2020). DINAMIKA POLITIK DESA Studi tentang Relasi Kuasa Elit Desa dan Politik Pilkades di Kecamatan Witihama Kabupaten Flores Timur. Warta Governare: Jurnal Ilmu Pemerintahan, 1(1), 1-14. https:// journal.unwira.ac.id/index.php/WG/article/ view/325

Wibisono, Y., \& Djumadin, Z. (2020). Kajian Teoritis Relasi dan Kepentingan Elit Lokal Partai di Era Otonomi. Ilmu Dan Budaya, 41(67), 78097820. http://journal.unas.ac.id/ilmu-budaya/ article/view/807 